\title{
RESPONSIBILITY OF FAT BODIES RELATED TO ENVIRONMENTAL FACTORS ON HONEYBEE (APIS MELLIFERA L.) (HYMENOPTERA: APIDAE) STRAINS IN KURDISTAN REGION
}

\author{
RuKhOSH, J. R..$^{1 *}$-TALAL, T. M. ${ }^{2}-$ ABDULBAST, M. A. ${ }^{3}$ \\ ${ }^{I}$ College of Agricultural Sciences, University of Sulaimani, Sulaymaniyah, Iraq \\ (e-mail: Rukhosh1983@yahoo.com) \\ ${ }^{2}$ College of Agriculture, University of Duhok, Duhok, Iraq \\ (e-mail: talphys_99@yahoo.com) \\ ${ }^{3}$ College of Agriculture, Salahaddin University-Erbil, Erbil, Iraq \\ (e-mail:profabed57@yahoo.com) \\ *Corresponding author \\ e-mail: rukhosh.rashed@univsul.edu.iq \\ (Received $16^{\text {th }}$ Oct 2018; accepted $22^{\text {nd }}$ Dec 2018)
}

\begin{abstract}
This study was carried out from April 2016 to the end of October 2017 including three seasons each year: Spring, early Summer, Summer and Autumn in the apiary of College of Agriculture Science in the University of Sulaimani - Kurdistan Region - Iraq. The results showed the highest rate of unsealed brood area for Apis mellifera Native was 1408.500 inch in early Summer 2016 and the lowest rate was 6.250 inch for Apis mellifera ligustica in Spring 2017, but the sealed brood area was 5906.500 inch for Apis mellifera Native strain in early Summer and the lowest rate was 22.000 inch for Apis mellifera Native strain in Autumn 2017. The highest and the lowest rate of Pollen grain area were (1582.750 and 7.290) inch for Apis mellifera Native strain in summer 2017 and 2016 respectively. Laboratory test indicated that the fat bodies play an important role in supplying the tissues with essential elements for body activities. Which means those fat bodies function as a reservoir.
\end{abstract}

Keywords: Apis mellifera L., foraging, honey production, nectar, pollen grain

\section{Introduction}

Foraging activity and behavior of Apis mellifera L. is dependent on many factors working at the same time, and the animals respond to some environmental conditions in a similar manner or method wherever they occur. Foraging for nectar and pollen is a continuous process throughout the year in tropical and sub-tropical regions, where the plants are available. However, the foraging activity of honey bees for pollen are significantly affected by weather conditions and availability of pollen (Neupane and Thapa, 2005). Foraging is one of the distinctive behaviors of honey bee (Apis mellifera L.), which links the honey bee colony and the surrounding environment (Abou-Shaara, 2014). It is known that the foraging activity for honeybees begin early in the morning and end in the evening. In some studies, honey bee workers started their foraging activity at 6.17 am in April, in one of the apple orchards (situated in Cheepa) in district Nainital of Kumaon Himalayas, Uttarakhand state of India. This start time however, may also be affected by the region (Joshi and Joshi, 2010). Al-qarni (2006) and BlazyteCereskiene et al. (2010) found that temperature has a significant impact on foraging activity, for example high temperature has a negative impact on foraging bees. Additionally, very low temperatures (below $10{ }^{\circ} \mathrm{C}$ ) can prevent flight. No significant 
direct effect of relative humidity was reported on honeybees, including foraging activity (Joshi and Joshi, 2010).

The fat bodies are normally distributed through the body cavity of insects, mostly in the abdomen where they appear as irregular masses of a soft and usually white tissue composed of large, loosely united cells. These cell masses are known collectively as fat body, because the cytoplasm of the cells contains small droplets of oily fat (Snodgrass and Erickson, 2003). The fat bodies can be irregularly distributed in the perivascular space of the abdomen and thorax, surrounding organs (visceral fat body) or in the dorsal and ventral sinus of the abdomen, close to the tegument (parietal fat body), in the head and even in body appendixes (Chapman, 1978; Zanini and Caetano, 2003). Ayoub (2011) found that the average dimension of a fat body cell in newly emerged workers ranges between 86.71 and $86.76 \mu \mathrm{m}$ and in 10-days old workers the average dimension of fat body cells ranges between 89.15 and $89.95 \mu \mathrm{m}$, while the average dimensions of fat body cell for foraging workers ranges between 67.33 and $69.05 \mu \mathrm{m}$.

Fat body is the main storage agent of the metabolic device of insects and is responsible for the synthesis and supply of hemolymph. Fatty body is made up of cells of the mesodermal origin, which sometimes contain epidermal cells (Oliveira and CruzLandim, 2003). Roma et al. (2010) demonstrated that fat body consists of a mass of cells under the epidermis, and in some insects, fat body also surrounds the digestive system and the reproductive system.

The aim of this work is to shed light on the factors related to bee activities, to find out the temperature most sufficient for long journeys (round trips) for each season in the study region, and to determine the adaptability of different bee races to environmental factors in different seasons of the year.

\section{Material and methods}

\section{Preparation and arrangement of colonies}

This study was carried out from April 2016 to the end of October 2017, and included three seasons per year; Spring, Summer, and Autumn. It was performed in the apiary of College of Agriculture Science in the University of Sulaimany - Iraq. We prepared four colonies of Apis mellifera carnica, four colonies of Apis mellifera ligustca, and four colonies of Apis mellifra Native, taking the following characteristics into account:

The queens were characterized by fertility, similar ages and being uniform in size in each race, therefore all experimental colonies included five frames each homogenous and uniform in activity. For measurements, two Langstroth frames were prepared at first, then it was modified by dividing each frame in to 17 inch in length and 8 inch in wide sections, Holes were inserted into each frame using frame fastening wires (silk), with each unit being one square inch, with a total of 136 units.

The area of the brood, honey and pollen were measured four seasons per year (spring, early summer, late summer and autumn of 2016 and 2017) using the standard Langstroth frame as described above. Also the area of unsealed and sealed broods was measured every 2 weeks until the end of the study. The measurement was taken using a typical frame with the method described by Mustafa (2003) and Targany (2008) (Figs. 1 and 2). 

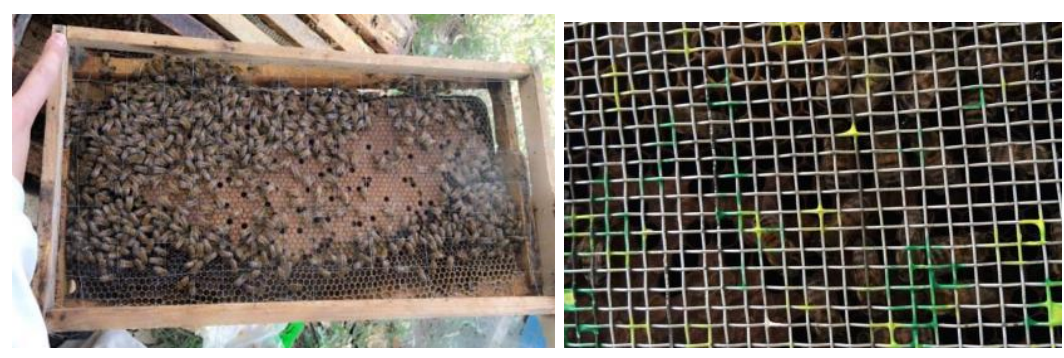

Figure 1. Typical frame

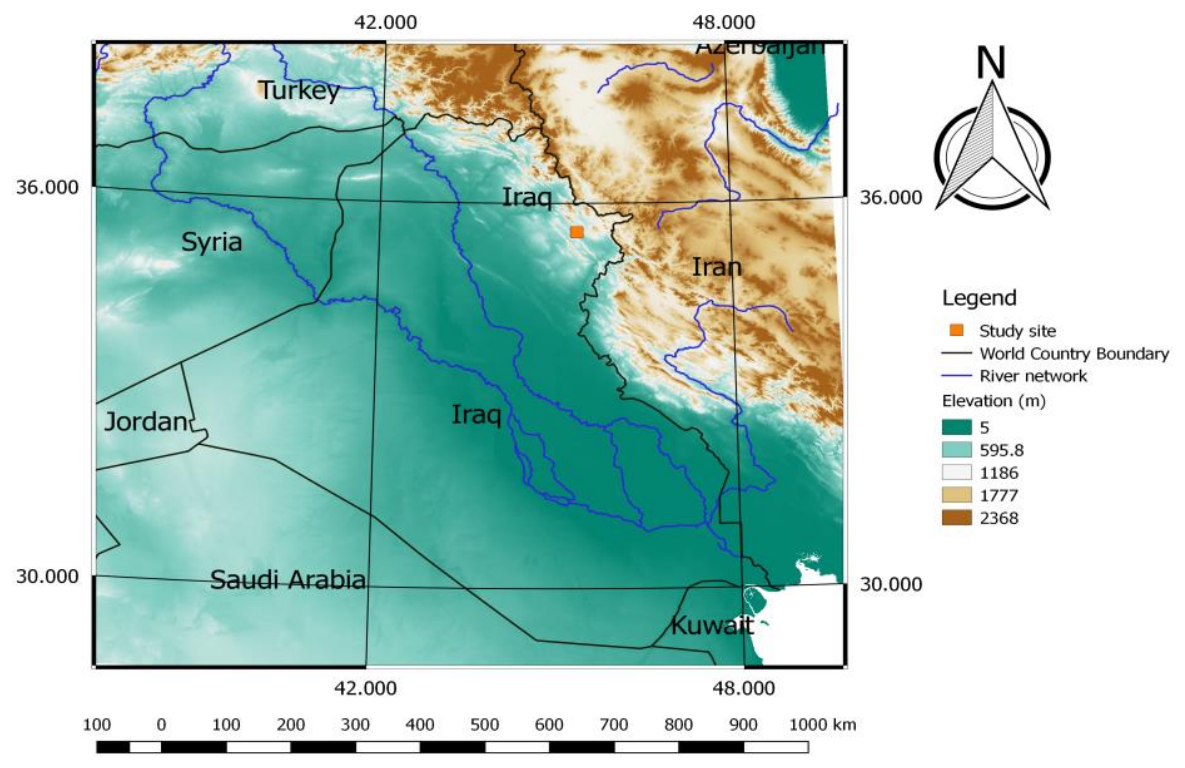

Figure 2. Map of the study site

\section{Labeling of samples}

Newly emerged workers were labeled with nail stains of different colors (Snodgrass and Erickson, 2003; Shamdin, 2003; Targany, 2008). One drop of the stain was stamped on the notum, characterized by little hairs, in a position where workers could not clean the label. The preliminary experiment was carried out in the laboratory in order to avoid any side effects of the stains on the viability of these young workers.

\section{Dissection}

The workers were fixed on the dissecting tray after the legs and wings were removed, and then were filled with physiological solution. Then the unit was transferred to the dissecting microscope, under which the head was cut off and placed on the filter paper for the measurement.

Workers were cut with a sharp scalpel into two lateral longitudinal slices of the abdomen. These were mounted on the dissecting tray by fine, stainless pins (Mahmoud, 1992; Shamdin, 2003). The workers were keep in a physiological saline with $0.9 \% \mathrm{w} / \mathrm{v}$ of $\mathrm{NaCl}, 0.9 \mathrm{~g}$ per $100 \mathrm{ml}$ distilled water (Pantin, 1964). The fixed workers were dissected under $2 \mathrm{x}$ and $4 \mathrm{x}$ objective lenses of binocular. After cutting the cuticle and 
removing the muscles, the fat bodies were picked up and placed on a clean slide and stained with methylene blue in normal limitation. The binocular dissecting and compound microscope for photographs and measurements was used with an eye piece graticule.

\section{The climatic data}

The data of climatic information was taken from Sulaimani General Directorate Meteorology and Seismology.

\section{Statistical analysis}

The results were analyzed statistically using factorial RCBD design with triple replicates and performed using the XLSTA program (2016). Duncan's multiple range Test was used to determine the differences between means at $\mathrm{P}=0.05$.

\section{Result and discussion}

\section{Effect of environmental factors on bioactivity of honey bee colonies in spring}

\section{Unsealed workers brood area}

Table 1 shows the average unsealed workers' brood area in spring. The highest average unsealed brood area of Apis mellifera ligustica was dated 14-5-2017 at $1316.250 \mathrm{inch}^{2}$, with an average temperature of $23.75^{\circ} \mathrm{C}$ and relative humidity of $38.95 \%$. The average unsealed brood area for Apis mellifera carnica and Apis mellifera Native were 1188.500 and 1086.500 inch. In the same period and weather conditions the lowest averages were $257.25,268.75$ and 266.500 inch $^{2}$ at 2-4-2016 and 253.000, 257.250 and 260.500 inch ${ }^{2}$ at 2-4-2017 for A. m. carnica, A. m. ligustica and A. m. Native respectively, with an average temperature of $15.75,16.5^{\circ} \mathrm{C}$ and relative humidity of $65.75 \%$ respectively.

Table 1. Effect of some honeybee races and environmental factors on unsealed brood area in spring 2016-2017

\begin{tabular}{|c|c|c|c|c|c|c|}
\hline Period & \multicolumn{3}{|c|}{ Honey bee race } & \multirow{2}{*}{ Mean } & Temperature & $\begin{array}{c}\text { Relative } \\
\text { humidity \% }\end{array}$ \\
\cline { 1 - 4 } Spring & $\begin{array}{c}\text { Apis mellifera } \\
\text { carnica }\end{array}$ & $\begin{array}{c}\text { Apis mellifera } \\
\text { ligustica }\end{array}$ & $\begin{array}{c}\text { Apis mellifera } \\
\text { Native }\end{array}$ & & & \\
\hline $2-4-2016$ & $257.250 \mathrm{j}$ & $268.750 \mathrm{ij}$ & $266.500 \mathrm{j}$ & 264.166 & 15.75 & 65.75 \\
\hline $16-4-2016$ & $292.250 \mathrm{hij}$ & $303.000 \mathrm{hij}$ & $295.000 \mathrm{hij}$ & 296.750 & 18.50 & 61.7 \\
\hline $30-4-2016$ & $350.500 \mathrm{gh}$ & $356.750 \mathrm{gh}$ & $344.750 \mathrm{ghi}$ & 350.666 & 21.50 & 59.75 \\
\hline $14-5-2016$ & $392.500 \mathrm{fg}$ & $381.750 \mathrm{~g}$ & $387.000 \mathrm{fg}$ & 387.083 & 24.50 & 46 \\
\hline $2-4-2017$ & $253.000 \mathrm{j}$ & $257.250 \mathrm{j}$ & $260.500 \mathrm{j}$ & 256.916 & 16.50 & 65.75 \\
\hline $16-4-2017$ & $487.000 \mathrm{e}$ & $477.750 \mathrm{e}$ & $456.750 \mathrm{ef}$ & 473.833 & 19.30 & 63.55 \\
\hline $30-4-2017$ & $660.000 \mathrm{~d}$ & $655.250 \mathrm{~d}$ & $643.250 \mathrm{~d}$ & 652.833 & 21.50 & 48.5 \\
\hline $14-5-2017$ & $1188.500 \mathrm{~b}$ & $1316.250 \mathrm{a}$ & $1086.500 \mathrm{c}$ & 1197.083 & 23.75 & 38.95 \\
\hline Mean & 485.125 & 385.785 & 467.531 & & 20.16 & 56.24375 \\
\hline
\end{tabular}

Different letters mean significant difference $(\mathrm{p}<0.05)$ based on Duncan test. 
Figure 3 shows the effect of honey bee races on the general average of unsealed brood worker area. These were 485.125, 467.531 and 385.785 inch for Apis mellifera carnica, Apis mellifera Native and Apis mellifea lugistica race respectively. Statistical analysis showed significant differences at level 0.05 among $A$. m. ligustica, A. m. carnica and $A$. $m$. Native at different temperatures and relative humidity. The results agree with Becher et al. (2009) who found that honey bees (Apis mellifera) are able to regulate incubation temperatures within a narrow range between 32 and $36{ }^{\circ} \mathrm{C}$. However, this small variation in brood temperature is sufficient to cause significant differences in the behavior of adult bees in agreement with Petz et al. (2004), who found the temperature, in particular, is very important for internal and external activities of honey bee colonies. Maintaining an appropriate degree of temperature from 33 to $36{ }^{\circ} \mathrm{C}$ within colonies is very important for honey bees.

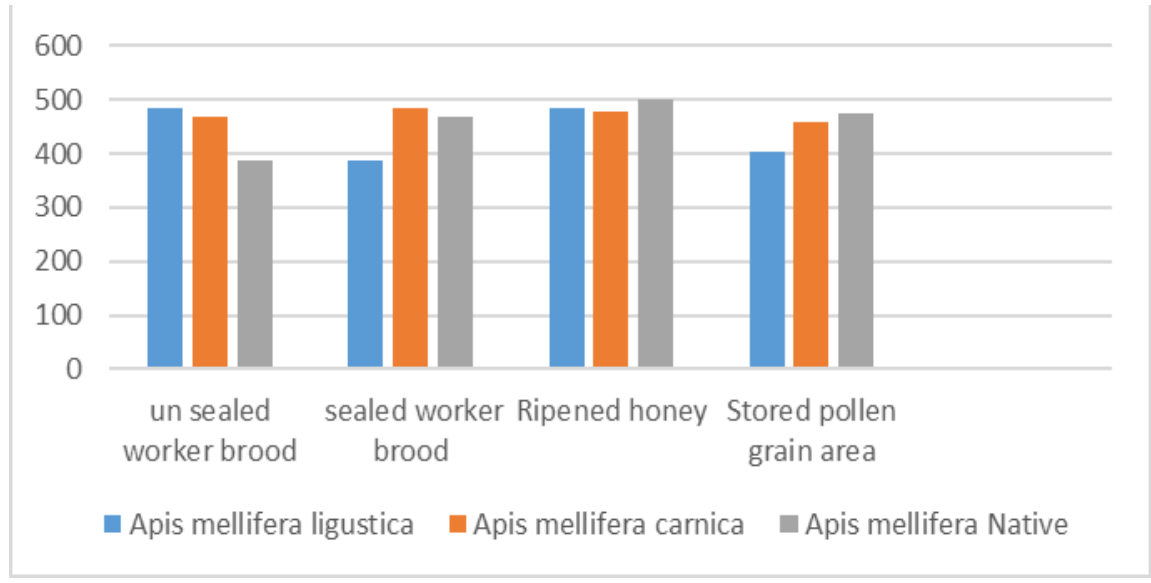

Figure 3. Effect of environmental conditions on the honeybee worker activities in spring

\section{Sealed workers brood area}

Table 2 shows the average sealed brood area of the workers in spring. The highest average sealed brood area for Apis mellefera ligustica was 1327.750 inch $^{2}$ with an average temperature of $23.75^{\circ} \mathrm{C}$ and average relative humidity of $38.95 \%$ at $14-5-2017$. Comparatively, the average sealed brood area for Apis mellifera carnica and Apis mellefera Native were 1137.750, 1098.500 inch $^{2}$ respectively during the same period and same weather conditions. Meanwhile, the lowest average of sealed brood was 261.000 inch $^{2}$ for $A$. m. ligustica at 2-4-2016, when the average temperature was $15.75{ }^{\circ} \mathrm{C}$ and the relative was humidity $65.75 \%$. At the date of $14-5-2017$ the highest general average was $1188.000 \mathrm{inch}^{2}$. Figure 3 shows the effect of the environmental conditions on $A$. $m$. carnica, A. $m$. Native, and A. $m$. ligustica. The general average of sealed brood area was 508.968, 501.812, and 514.187 inch $^{2}$ respectively. Statistical analysis showed significant differences at level 0.05 between races. According to the results, the sealed worker broods were in high numbers during spring, which is in accordance with Fathy (1997), who found that the results showed that the main peak of brood activity and a high rate of stored pollen were observed in May, and therefore the maximum number of bees was recorded during June and July. However, there is no reciprocal relationship. The lowest level of brood, bee and pollen production occurred during February. 
Table 2. Effect of some honeybee races and environmental factors on sealed brood area in the spring season of 2016-2017

\begin{tabular}{|c|c|c|c|c|c|c|}
\hline Period & \multicolumn{3}{|c|}{ Honeybee race } & \multirow{2}{*}{ Mean } & Temperature & $\begin{array}{c}\text { Relative } \\
\text { humidity \% }\end{array}$ \\
\hline Spring & $\begin{array}{c}\text { Apis mellefera } \\
\text { carnica }\end{array}$ & $\begin{array}{c}\text { Apis mellefera } \\
\text { ligustica }\end{array}$ & $\begin{array}{c}\text { Apis mellefera } \\
\text { Native }\end{array}$ & & & \\
\hline $2-4-2016$ & $274.750 \mathrm{j}$ & $261.000 \mathrm{j}$ & $297.000 \mathrm{hij}$ & 277.583 & 15.75 & 65.75 \\
\hline $16-4-2016$ & $311.250 \mathrm{ghij}$ & $289.250 \mathrm{ij}$ & $326.250 \mathrm{ghij}$ & 308.916 & 18.50 & 61.70 \\
\hline $30-4-2016$ & $390.250 \mathrm{efg}$ & $342.500 \mathrm{fghij}$ & $380.250 \mathrm{efgh}$ & 371.000 & 21.50 & 59.75 \\
\hline $14-5-2016$ & $429.250 \mathrm{e}$ & $371.250 \mathrm{efghi}$ & $425.250 \mathrm{ef}$ & 408.583 & 24.50 & 46.00 \\
\hline $2-4-2017$ & $277.000 \mathrm{j}$ & $267.000 \mathrm{j}$ & $296.500 \mathrm{hij}$ & 280.166 & 16.50 & 65.75 \\
\hline $16-4-2017$ & $539.500 \mathrm{~d}$ & $544.750 \mathrm{~d}$ & $506.250 \mathrm{~d}$ & 530.166 & 19.30 & 63.55 \\
\hline $30-4-2017$ & $712.000 \mathrm{c}$ & $710.000 \mathrm{c}$ & $684.500 \mathrm{c}$ & 702.166 & 21.50 & 48.50 \\
\hline $14-5-2017$ & $1137.750 \mathrm{~b}$ & $1327.750 \mathrm{a}$ & $1098.500 \mathrm{~b}$ & 1188.000 & 23.75 & 38.95 \\
\hline Mean & 508.968 & 514.187 & 501.812 & & 20.16 & 56.24 \\
\hline
\end{tabular}

Different letters mean significant difference $(\mathrm{p}<0.05)$ based on Duncan test.

\section{Ripened honey}

Table 3 shows the average ripened honey area in spring. The highest average area for A. $m$. ligustica was 1565.750 inch $^{2}$ at $14-5-2017$ when the average temperature was $23.75^{\circ} \mathrm{C}$ and the relative humidity was $38.95 \%$. The average area for A. m. carnica and A. $m$. Native were 1535.750 and $1542.750 \mathrm{inch}^{2}$ during the same period and with the same weather conditions, but the lowest average for the A. m. carnica was 215.750 inch $^{2}$ in 2-4-2017 when the average temperature and relative humidity was $16.5^{\circ} \mathrm{C}$ and $65.75 \%$. The average of ripened honey area was $476.25,482.9688$ and $499.6875 \mathrm{inch}^{2}$ for A. m. carnica, A. m. ligustica and A. $m$. Native respectively. The highest general average was $1548.083 \mathrm{inch}^{2}$ at the date of 14 5-2017 and the lowest was 237.166 inch $^{2}$ in 16-4-2016. Figure 3 shows the effect of environmental conditions on A. m. carnica, A. m. ligustica and A. $m$. Native. The general average of ripened honey area in spring was $476.250,482.968$ and $499.687 \mathrm{inch}^{2}$ respectively. Statistical analysis showed significant differences at level 0.05 among races. According to the results, the amount of honey was high for all races in spring season due to flowering. This matches the findings of Mattu et al. (2012) who studied the times at which foraging starts and stops, the duration of the foraging and length of trips, as well as the number of flowers visited per minute.

Table 3. Effect of some honeybee races and environmental factors on ripened honey area in spring season 2016-2017

\begin{tabular}{|c|c|c|c|c|c|c|}
\hline Period & \multicolumn{3}{|c|}{ Honeybee race } & \multirow{2}{*}{ Mean } & Temperature & $\begin{array}{c}\text { Relative } \\
\text { humidity \% }\end{array}$ \\
\hline Spring & $\begin{array}{c}\text { Apis mellifera } \\
\text { carnica }\end{array}$ & $\begin{array}{c}\text { Apis mellifera } \\
\text { ligustica }\end{array}$ & $\begin{array}{c}\text { Apis mellifera } \\
\text { Native }\end{array}$ & & & \\
\hline $2-4-2016$ & $236.500 \mathrm{de}$ & $234.500 \mathrm{de}$ & $273.000 \mathrm{de}$ & 248.000 & 15.75 & 65.75 \\
\hline $16-4-2016$ & $222.250 \mathrm{de}$ & $234.250 \mathrm{de}$ & $255.000 \mathrm{de}$ & 237.166 & 18.50 & 61.7 \\
\hline $30-4-2016$ & $232.750 \mathrm{de}$ & $240.250 \mathrm{de}$ & $277.750 \mathrm{~d}$ & 250.250 & 21.50 & 59.75 \\
\hline $14-5-2016$ & $228.500 \mathrm{de}$ & $252.750 \mathrm{de}$ & $268.250 \mathrm{de}$ & 249.833 & 24.50 & 46.00 \\
\hline $2-4-2017$ & $215.750 \mathrm{e}$ & $237.000 \mathrm{de}$ & $268.750 \mathrm{de}$ & 240.500 & 16.50 & 65.75 \\
\hline $16-4-2017$ & $392.500 \mathrm{c}$ & $400.250 \mathrm{c}$ & $405.750 \mathrm{c}$ & 399.500 & 19.30 & 63.55 \\
\hline $30-4-2017$ & $746.000 \mathrm{~b}$ & $699.000 \mathrm{~b}$ & $706.250 \mathrm{~b}$ & 717.083 & 21.50 & 48.50 \\
\hline $14-5-2017$ & $1535.750 \mathrm{a}$ & $1565.750 \mathrm{a}$ & $1542.750 \mathrm{a}$ & 1548.083 & 23.75 & 38.95 \\
\hline Mean & 476.25 & 482.968 & 499.687 & & 20.16 & 56.24 \\
\hline
\end{tabular}

Different letters mean significant difference $(\mathrm{p}<0.05)$ based on Duncan test. 


\section{Stored pollen grain area}

Table 4 and Figure 3 show the average stored pollen grain area in spring. The highest average area for $A$. $m$. carnica was $1111.000 \mathrm{inch}^{2}$ at 14-5-2017 when the average temperature was $23.75^{\circ} \mathrm{C}$ and the relative humidity was $38.95 \%$. The average area for $A$. $m$. Native and A. m. ligustica were 1088.750 and 972.500 inch $^{2}$ during the same period and the lowest average was $218.750 \mathrm{inch}^{2}$ for Apis mellifera carnica at 2-4-2017 when the average temperature and relative humidity was $16.5^{\circ} \mathrm{C}$ and $65.75 \%$. The average of stored pollen area was $474.062,457.687$ and 402.416 inch $^{2}$ for $A$. $m$. Native, A. $m$. carnica and A. m. ligustica respectively when the temperature was $20.16^{\circ} \mathrm{C}$ and the average relative humidity was $56.24 \%$. The highest general average was $1057.417 \mathrm{inch}^{2}$ at the date of 14-5-2017 and the lowest was 231.583 inch $^{2}$ at 2-4-2016. Statistical analysis showed significant differences at level 0.05 among all three races. The results agree with Neupane and Thapa (2005) who found that the foraging activity of honey bees for pollen are significantly affected by the weather condition and availability of pollen.

Table 4. Effect of some honeybee races and environmental factors on pollen grain area in spring season 2016-2017

\begin{tabular}{|c|c|c|c|c|c|c|}
\hline Period & \multicolumn{3}{|c|}{ Honey bee race } & \multirow{2}{*}{ Mean } & Temperature & $\begin{array}{c}\text { Relative } \\
\text { humidity \% }\end{array}$ \\
\hline Spring & $\begin{array}{c}\text { Apis mellifera } \\
\text { carnica }\end{array}$ & $\begin{array}{c}\text { Apis mellifera } \\
\text { ligustica }\end{array}$ & $\begin{array}{c}\text { Apis mellifera } \\
\text { Native }\end{array}$ & & & \\
\hline $2-4-2016$ & $221.000 \mathrm{~h}$ & $216.000 \mathrm{~h}$ & $257.750 \mathrm{fgh}$ & 231.583 & 15.75 & 65.75 \\
\hline $16-4-2016$ & $241.250 \mathrm{fgh}$ & $221.000 \mathrm{~h}$ & $278.000 \mathrm{fgh}$ & 246.750 & 18.50 & 61.70 \\
\hline $30-4-2016$ & $266.250 \mathrm{fgh}$ & $244.250 \mathrm{fgh}$ & $297.000 \mathrm{fg}$ & 269.166 & 21.50 & 59.75 \\
\hline $14-5-2016$ & $303.000 \mathrm{ef}$ & $269.250 \mathrm{fgh}$ & $364.250 \mathrm{e}$ & 312.166 & 24.50 & 46.00 \\
\hline $2-4-2017$ & $218.750 \mathrm{~h}$ & $230.250 \mathrm{fgh}$ & $286.500 \mathrm{fgh}$ & 245.166 & 16.50 & 65.75 \\
\hline $16-4-2017$ & $544.250 \mathrm{~d}$ & $751.500 \mathrm{c}$ & $494.000 \mathrm{~d}$ & 596.583 & 19.30 & 63.55 \\
\hline $30-4-2017$ & $756.000 \mathrm{c}$ & $751.500 \mathrm{C}$ & $726.250 \mathrm{c}$ & 744.583 & 21.50 & 48.50 \\
\hline $14-5-2017$ & $1111.000 \mathrm{a}$ & $972.500 \mathrm{~b}$ & $1088.750 \mathrm{a}$ & 1057.417 & 23.750 & 38.95 \\
\hline Mean & 457.687 & 402.416 & 474.062 & & 20.162 & 56.24 \\
\hline
\end{tabular}

Different letters mean significant difference $(\mathrm{p}<0.05)$ based on Duncan test.

\section{Effect of environmental factors on bioactivity of honey bee colonies in early summer}

\section{Unsealed workers brood area}

Table 5 shows the average unsealed workers brood area in early summer. The highest average unsealed brood area for $A$. $m$. Native at the date of 28-5-2017 was $1408.500 \mathrm{inch}^{2}$ when the average temperature was $26.50{ }^{\circ} \mathrm{C}$ and the average relative humidity was $36.50 \%$. The average unsealed brood area for A. m. carnica and A. $m$. ligustica were 1333.250 and 1371.750 inch $^{2}$ during the same period and weather conditions, while the lowest average was $132.250 \mathrm{inch}^{2}$ at 9-7-2016 and 767.937, 750.937 and 770.781 inch $^{2}$ at 9-7-2016 for A. m. carnica, A. m. ligustica and A. m. Native respectively, as in shown in Figure 4. Statistical analysis showed significant differences at level 0.05 among studied races. Abou-Shaara et al., (2012) also found 
positive correlations between foraging activities and sealed brood area as well as bee numbers.

Table 5. Effect of some honeybee races and environmental factors on unsealed brood area in early summer 2016-2017

\begin{tabular}{|c|c|c|c|c|c|c|}
\hline Period & \multicolumn{3}{|c|}{ Honeybee race } & \multirow[b]{2}{*}{ Mean } & \multirow[b]{2}{*}{ Temperature } & \multirow{2}{*}{$\begin{array}{c}\text { Relative } \\
\text { humidity \% }\end{array}$} \\
\hline Early summer & $\begin{array}{c}\text { Apis mellifera } \\
\text { carnica }\end{array}$ & $\begin{array}{c}\text { Apis mellifera } \\
\text { ligustica }\end{array}$ & $\begin{array}{c}\text { Apis mellifera } \\
\text { Native }\end{array}$ & & & \\
\hline $28 / 5 / 2016$ & $438.000 \mathrm{e}$ & $413.750 \mathrm{e}$ & $439.500 \mathrm{e}$ & 430.416 & 26.75 & 44.00 \\
\hline $11 / 6 / 2016$ & $446.500 \mathrm{e}$ & $422.250 \mathrm{e}$ & $428.750 \mathrm{e}$ & 432.500 & 28.00 & 35.50 \\
\hline $25 / 6 / 2016$ & $405.750 \mathrm{e}$ & $393.750 \mathrm{e}$ & $386.750 \mathrm{e}$ & 395.416 & 30.50 & 31.75 \\
\hline 9/7/2016 & $138.750 \mathrm{f}$ & $133.000 \mathrm{f}$ & $132.250 \mathrm{f}$ & 134.666 & 34.50 & 27.30 \\
\hline $28 / 5 / 2017$ & $1333.250 \mathrm{ab}$ & $1371.750 \mathrm{a}$ & $1408.500 \mathrm{a}$ & 1371.167 & 26.50 & 36.50 \\
\hline $11 / 6 / 2017$ & $1332.000 \mathrm{ab}$ & $1313.500 \mathrm{ab}$ & $1229.000 \mathrm{~b}$ & 1291.500 & 32.40 & 30.65 \\
\hline $25 / 6 / 2017$ & $1019.250 \mathrm{~cd}$ & $936.500 \mathrm{~d}$ & $1024.750 \mathrm{~cd}$ & 993.500 & 33.50 & 23.50 \\
\hline 9/7/2017 & $1030.000 \mathrm{~cd}$ & $1023.000 \mathrm{~cd}$ & $1116.750 \mathrm{c}$ & 1056.583 & 34.85 & 22.60 \\
\hline Mean & 767.937 & 750.937 & 770.781 & & 30.87 & 31.47 \\
\hline
\end{tabular}

Different letters mean significant difference $(\mathrm{p}<0.05)$ based on Duncan test.

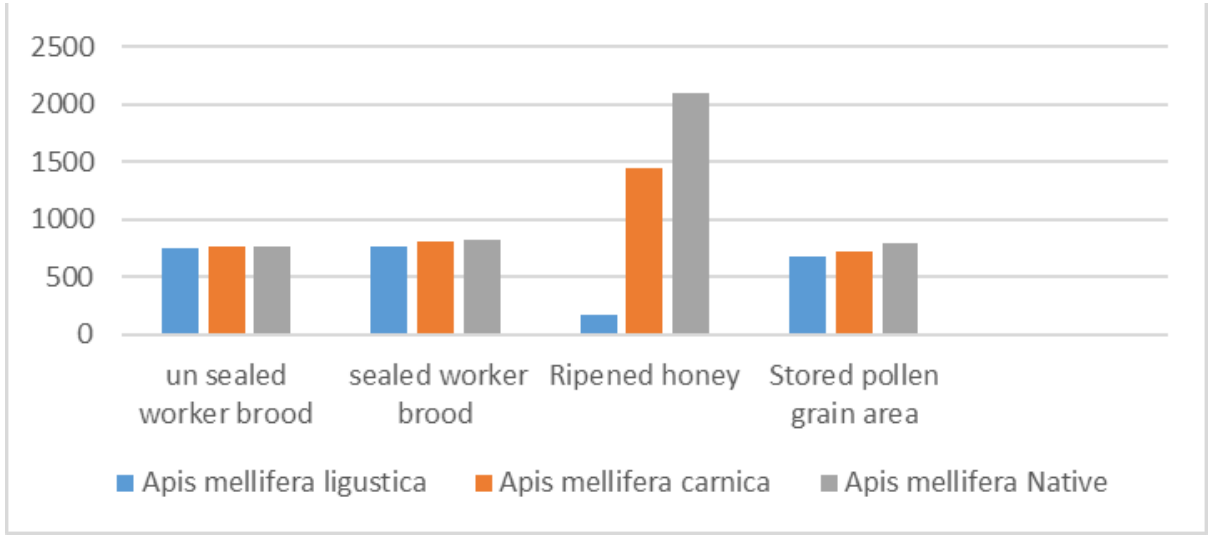

Figure 4. Effect of environmental factors on different the activities of honeybee races in early summer

\section{Sealed workers brood area}

Table 6 and Figure 4 show the average sealed brood area of the workers in early summer. The highest average sealed brood area for $A$. $m$. Native $1514.750 \mathrm{inch}^{2}$ at 28-52017 when the average temperature was $26.50{ }^{\circ} \mathrm{C}$ and the average relative humidity was $36.50 \%$. The average sealed brood area for A. m. carnica and A. m. ligustica were 1404.250 and 1319.750 inch $^{2}$ during the same period and weather conditions, while the lowest average of sealed brood was 101.500 inch $^{2}$ for $A$. $m$. Native at 9-7-2016, when the average temperature and relative humidity were $34.50{ }^{\circ} \mathrm{C}$ and $27.30 \%$. The average of sealed workers brood area was 823.843, 803.625 and 770.312 inch $^{2}$ for $A$. $m$. Native, A. $m$. carnica and A. m. ligustica respectively, when the average temperature was $30.87^{\circ} \mathrm{C}$ and average relative humidity was $31.47 \%$ ). The highest general average was 
1412.917 inch $^{2}$ in 28-5-2017 and the lowest was 107.000 inch $^{2}$ at 9-7-2016. Statistical analysis showed significant differences at level 0.05 among races. Harbo (2015) found that the bees used a total of 121 grams of honey to produce 1,000 cells of the brood (eggs, larvae, and virgins in the normal brood nest) and about $163 \mathrm{mg}$ of honey to rear the working bees to the virgin stage. In colonies containing incubation of all stages, brood weight was approximately equal to (about $25 \%$ less than) the weight of the honey used in its production.

Table 6. Effect of some honeybee races and environmental factors on sealed brood area in early summer 2016-2017

\begin{tabular}{|c|c|c|c|c|c|c|}
\hline Period & \multicolumn{3}{|c|}{ Honeybee race } & \multirow{2}{*}{ Mean } & Temperature & $\begin{array}{c}\text { Relative } \\
\text { humidity \% }\end{array}$ \\
\cline { 1 - 3 } Early summer & $\begin{array}{c}\text { Apis mellifera } \\
\text { carnica }\end{array}$ & $\begin{array}{c}\text { Apis mellifera } \\
\text { ligustica }\end{array}$ & $\begin{array}{c}\text { Apis mellifera } \\
\text { Native }\end{array}$ & & & \\
\hline $28 / 5 / 2016$ & $473.250 \mathrm{f}$ & $417.750 \mathrm{f}$ & $475.250 \mathrm{f}$ & 455.416 & 26.75 & 44.00 \\
\hline $11 / 6 / 2016$ & $484.500 \mathrm{f}$ & $434.000 \mathrm{f}$ & $462.500 \mathrm{f}$ & 460.333 & 28.00 & 35.50 \\
\hline $25 / 6 / 2016$ & $459.000 \mathrm{f}$ & $412.750 \mathrm{f}$ & $438.750 \mathrm{f}$ & 436.833 & 30.50 & 31.75 \\
\hline $9 / 7 / 2016$ & $110.000 \mathrm{~g}$ & $109.500 \mathrm{~g}$ & $101.500 \mathrm{~g}$ & 107.000 & 34.50 & 27.30 \\
\hline $28 / 5 / 2017$ & $1404.250 \mathrm{ab}$ & $1319.750 \mathrm{~b}$ & $1514.750 \mathrm{a}$ & 1412.917 & 26.50 & 36.50 \\
\hline $11 / 6 / 2017$ & $1389.000 \mathrm{ab}$ & $1427.500 \mathrm{ab}$ & $1404.250 \mathrm{ab}$ & 1406.917 & 32.40 & 30.65 \\
\hline $25 / 6 / 2017$ & $1109.750 \mathrm{~cd}$ & $1081.750 \mathrm{cde}$ & $1143.750 \mathrm{c}$ & 1111.750 & 33.50 & 23.50 \\
\hline $9 / 7 / 2017$ & $999.250 \mathrm{de}$ & $959.500 \mathrm{e}$ & $1050.000 \mathrm{cde}$ & 1002.917 & 34.85 & 22.60 \\
\hline Mean & 803.625 & 770.312 & 823.843 & & 30.87 & 31.47 \\
\hline
\end{tabular}

Different letters mean significant difference $(\mathrm{p}<0.05)$ based on Duncan test.

\section{Ripened honey area}

Table 7 shows the average ripened honey area in early summer. The highest average area for $A$. $m$. Native was 5906.500 $\mathrm{inch}^{2}$ at 25-6-2017 when the average temperature was $33.50{ }^{\circ} \mathrm{C}$ and the relative humidity was $23.50 \%$. In comparison, the average area for A. m. carnica and A. m. ligustica were 4813.750 and $3781.000 \mathrm{inch}^{2}$ during the same period and weather conditions. The lowest average for $A$. m. ligustica and $A$. $m$. Native was $243.000 \mathrm{inch}^{2}$ at 9-7-2016 when the average temperature and relative humidity were $34.50{ }^{\circ} \mathrm{C}$ and $22.60 \%$. The average of ripened honey area was $2103.000,1793.156$ and 1453.375 inch $^{2}$ for $A$. $m$. Native, A. m. carnica and A. m. ligustica respectively as show in Figure 4.

Table 7. Effect of some honeybee races and environmental factors on sealed honey area in early summer 2016-2017

\begin{tabular}{|c|c|c|c|c|c|c|}
\hline Period & \multicolumn{3}{|c|}{ Honey bee race } & \multirow{2}{*}{ Mean } & Temperature & $\begin{array}{c}\text { Relative } \\
\text { humidity \% }\end{array}$ \\
\cline { 1 - 4 } Early summer & $\begin{array}{c}\text { Apis mellifera } \\
\text { carnica }\end{array}$ & $\begin{array}{c}\text { Apis mellifera } \\
\text { ligustica }\end{array}$ & $\begin{array}{c}\text { Apis mellifera } \\
\text { Native }\end{array}$ & & & \\
\hline $28 / 5 / 2016$ & $244.250 \mathrm{~g}$ & $272.000 \mathrm{~g}$ & $283.250 \mathrm{~g}$ & 266.500 & 26.75 & 44.00 \\
\hline $11 / 6 / 2016$ & $288.000 \mathrm{~g}$ & $296.500 \mathrm{~g}$ & $315.250 \mathrm{~g}$ & 299.916 & 28.00 & 35.50 \\
\hline $25 / 6 / 2016$ & $288.000 \mathrm{~g}$ & $316.000 \mathrm{~g}$ & $324.000 \mathrm{~g}$ & 309.333 & 30.50 & 31.75 \\
\hline $9 / 7 / 2016$ & $247.000 \mathrm{~g}$ & $243.000 \mathrm{~g}$ & $243.000 \mathrm{~g}$ & 244.333 & 34.50 & 27.30 \\
\hline $28 / 5 / 2017$ & $3143.500 \mathrm{~d}$ & $2186.000 \mathrm{e}$ & $3387.750 \mathrm{~cd}$ & 2905.750 & 26.50 & 36.50 \\
\hline
\end{tabular}




\begin{tabular}{|c|c|c|c|c|c|c|}
\hline $11 / 6 / 2017$ & $3785.000 \mathrm{c}$ & $2966.750 \mathrm{~d}$ & $4821.500 \mathrm{~b}$ & 3857.750 & 32.40 & 30.65 \\
\hline $25 / 6 / 2017$ & $4813.750 \mathrm{~b}$ & $3781.000 \mathrm{c}$ & $5906.500 \mathrm{a}$ & 4833.750 & 33.50 & 23.50 \\
\hline $9 / 7 / 2017$ & $1535.750 \mathrm{f}$ & $1565.750 \mathrm{f}$ & $1542.750 \mathrm{f}$ & 1548.083 & 34.85 & 22.60 \\
\hline Mean & 1793.156 & 1453.375 & 2103.000 & & 30.87 & 31.47 \\
\hline
\end{tabular}

Different letters mean significant difference $(\mathrm{p}<0.05)$ based on Duncan test.

The highest general average was $4833.750 \mathrm{inch}^{2}$ in 25-6-2017 and the lowest was 244.333 inch $^{2}$ at 9-7-2016. Statistical analysis showed significant differences at level 0.05 among $A$. $m$. carnica, $A$. $m$. local and A. m. ligustica. The results agree with Tirado et al. (2013) who indicated that Climate change is associated with a marked disparity in the abundance of honey bees and honey yield. Foraging activities of social insects are affected by climate.

\section{Stored pollen grain area}

Table 8 shows the average stored pollen grain area in early summer. The highest average area for $A$. $m$. Native was $1575.500 \mathrm{inch}^{2}$ at 25-6-2017, when the average temperature was $33.50{ }^{\circ} \mathrm{C}$ and relative humidity was $23.50 \%$. The average area for $A . m$. carnica and A. m. ligustica were 1401.000 and 1268.750 inch $^{2}$ during the same period and weather conditions. The lowest average was $78.500 \mathrm{inch}^{2}$ for $A . m$. Native at 9-72016 when the average temperature and relative humidity were $34.50{ }^{\circ} \mathrm{C}$ and $27.30 \%$. The average of stored pollen area was 789.000, 716.281 and 673.906 inch $^{2}$ for A. $m$. Native, A. m. carnica and A. m. ligustica, with a temperature of $30.87^{\circ} \mathrm{C}$ and an average relative humidity of $31.47 \%$ as shown in Figure 4 . The highest general average was 1415.083 $\mathrm{inch}^{2}$ at 25-6-2017 and the lowest was 87.500 $\mathrm{inch}^{2}$ at 9-7-2016. Statistical analysis showed significant differences at level 0.05 among $A$. $m$. carnica, A. $m$. Native and A. m. ligustica. The result agree with Mesbah et al. (2017), who showed that the largest quantity of pollen was in August and the summer season, while the lowest was in May and the spring season. Also the highest mean area of brood and honey sealed in trap colonies and without a trap was in September, while the lowest was in May in colonies both with and without traps.

Table 8. Effect of some honeybee races and environmental factors on pollen grain area in early summer 2016-2017

\begin{tabular}{|c|c|c|c|c|c|c|}
\hline Early summer & $\begin{array}{c}\text { Apis mellifera } \\
\text { carnica }\end{array}$ & $\begin{array}{c}\text { Apis mellifera } \\
\text { ligustica }\end{array}$ & $\begin{array}{c}\text { Apis mellifera } \\
\text { Native }\end{array}$ & Mean & Temperature & $\begin{array}{c}\text { Relative } \\
\text { humidity \% }\end{array}$ \\
\hline $28 / 5 / 2016$ & $332.250 \mathrm{gh}$ & $307.500 \mathrm{gh}$ & $390.000 \mathrm{~g}$ & 343.250 & 26.75 & 44.00 \\
\hline $11 / 6 / 2016$ & $352.000 \mathrm{gh}$ & $294.500 \mathrm{gh}$ & $380.500 \mathrm{~g}$ & 342.333 & 28.00 & 35.50 \\
\hline $25 / 6 / 2016$ & $303.250 \mathrm{gh}$ & $244.250 \mathrm{~h}$ & $323.000 \mathrm{gh}$ & 290.166 & 30.50 & 31.75 \\
\hline $9 / 7 / 2016$ & $86.000 \mathrm{i}$ & $97.250 \mathrm{i}$ & $78.500 \mathrm{i}$ & 87.250 & 34.50 & 27.30 \\
\hline $28 / 5 / 2017$ & $1047.250 \mathrm{ef}$ & $967.500 \mathrm{f}$ & $979.750 \mathrm{f}$ & 998.166 & 26.50 & 36.50 \\
\hline $11 / 6 / 2017$ & $1027.500 \mathrm{ef}$ & $982.000 \mathrm{f}$ & $1102.500 \mathrm{de}$ & 1037.333 & 32.40 & 30.65 \\
\hline $25 / 6 / 2017$ & $1401.000 \mathrm{~b}$ & $1268.750 \mathrm{c}$ & $1575.500 \mathrm{a}$ & 1415.083 & 33.50 & 23.50 \\
\hline $9 / 7 / 2017$ & $1181.000 \mathrm{~cd}$ & $1229.500 \mathrm{c}$ & $1482.250 \mathrm{ab}$ & 1297.583 & 34.85 & 22.60 \\
\hline Mean & 716.281 & 673.906 & 789.000 & & 30.87 & 31.47 \\
\hline
\end{tabular}

Different letters mean significant difference $(\mathrm{p}<0.05)$ based on Duncan test. 


\section{Effect of environmental factors on bioactivity of honey bee colonies in late summer}

\section{Unsealed workers brood area}

Table 9 shows the average unsealed workers brood area in summer. The highest average unsealed brood area for $A$. $m$. Native at 23-7-2017 was 920.250 inch $^{2}$ when the average temperature was $32.75^{\circ} \mathrm{C}$ and the average relative humidity was $24.15 \%$. The average unsealed brood area for A. m. carnica and A. m. ligustica was 773.500 and $753.000 \mathrm{inch}^{2}$ during the same period and weather conditions, while the lowest average of unsealed brood area was $86.250 \mathrm{inch}^{2}$ for $A$. $m$. Native at 6-8-2016 when the average temperature and relative humidity were $43.95^{\circ} \mathrm{C}$ and $24.30 \%$. The average of unsealed workers brood area was 382.250, 328.781 and $289.875 \mathrm{inch}^{2}$ for A. $m$. Native, $A . m$. carnica and, A. m. ligustica respectively with an average temperature of $36.11^{\circ} \mathrm{C}$ and average relative humidity of $27.31 \%$ as shows in Figure 5. The highest general average was 815.583 inch $^{2}$ at 23-7-2017 and the lowest was 104.583 inch $^{2}$ at 6-8-2016. Statistical analysis showed significant differences at level 0.05 among A. m. carnica, Apis mellifera Native and A. m. ligustica. Reddy et al. (2012) also found that at the same ambient temperature, outgoing $A$. mellifera foragers and workers who were sampled from the brood nest had a higher chest temperature, much higher than leaving A. cerana foragers and brood nest workers. A. mellifera colonies also maintained a brood temperature significantly higher than A. cerana. Our findings indicate that the larger A. mellifera foragers require higher chest temperature to be able to forage in the apiary in Kunming, China.

Table 9. Effect of some honeybee races and environmental factors on unsealed brood area in summer 2016-2017

\begin{tabular}{|c|c|c|c|c|c|c|}
\hline Summer & \multicolumn{3}{|c|}{ Honey bee race } & \multirow{2}{*}{ Mean } & Temperature & $\begin{array}{c}\text { Relative } \\
\text { humidity \% }\end{array}$ \\
\cline { 1 - 4 } Period & $\begin{array}{c}\text { Apis mellifera } \\
\text { carnica }\end{array}$ & $\begin{array}{c}\text { Apis mellifera } \\
\text { ligustica }\end{array}$ & $\begin{array}{c}\text { Apis mellifera } \\
\text { Native }\end{array}$ & & & \\
\hline $23 / 7 / 2016$ & $115.250 \mathrm{~g}$ & $112.250 \mathrm{~g}$ & $105.750 \mathrm{~g}$ & 111.083 & 34.05 & 25.85 \\
\hline $6 / 8 / 2016$ & $115.250 \mathrm{~g}$ & $112.250 \mathrm{~g}$ & $86.250 \mathrm{~g}$ & 104.583 & 43.95 & 24.3 \\
\hline $20 / 8 / 2016$ & $130.250 \mathrm{~g}$ & $116.500 \mathrm{~g}$ & $102.250 \mathrm{~g}$ & 116.333 & 42.50 & 26.95 \\
\hline $3 / 9 / 2016$ & $152.000 \mathrm{~g}$ & $139.750 \mathrm{~g}$ & $121.750 \mathrm{~g}$ & 137.833 & 34.50 & 35.7 \\
\hline $23 / 7 / 2017$ & $773.500 \mathrm{~b}$ & $753.000 \mathrm{bc}$ & $920.250 \mathrm{a}$ & 815.583 & 32.75 & 24.15 \\
\hline $6 / 8 / 2017$ & $529.000 \mathrm{~d}$ & $406.000 \mathrm{e}$ & $688.000 \mathrm{c}$ & 541 & 36.70 & 24.5 \\
\hline $20 / 8 / 2017$ & $398.750 \mathrm{ef}$ & $326.500 \mathrm{f}$ & $505.250 \mathrm{~d}$ & 410.166 & 34.60 & 26.44 \\
\hline $3 / 9 / 2017$ & $416.250 \mathrm{e}$ & $352.750 \mathrm{ef}$ & $528.500 \mathrm{~d}$ & 432.5 & 29.90 & 30.65 \\
\hline Mean & 328.781 & 289.875 & 382.250 & & 36.11 & 27.317 \\
\hline
\end{tabular}

Different letters mean significant difference $(\mathrm{p}<0.05)$ based on Duncan test.

\section{Sealed workers brood area}

Table 10 and Figure 5 show the average sealed brood area of the workers in summer. The highest average sealed brood area for $A$. $m$. Native $948.250 \mathrm{inch}^{2}$ at 23-7-2017, when the average temperature was $32.75^{\circ} \mathrm{C}$ and the average relative humidity was $24.15 \%$. In comparison, the average sealed brood area for A. m. carnica and A. $\mathrm{m}$. ligustica were 939.500 and 795.500 inch $^{2}$ during the same period and weather conditions, while the lowest average of sealed brood was $61.250 \mathrm{inch}^{2}$ for $A . m$. 
ligustica at 20-8-2016, when the average temperature and relative humidity were $42.50{ }^{\circ} \mathrm{C}$ and $26.95 \%$ respectively. The average of sealed workers brood area was 397.968, 372.187 and 315.031 inch $^{2}$ for A. $m$. Native, A. $m$. carnica and A. m. ligustica respectively, when the average temperature was $36.11^{\circ} \mathrm{C}$ and the average relative humidity was $27.31 \%$. The highest general average was 894.41 inch $^{2}$ at 23-7-2017 and the lowest was $62.916 \mathrm{inch}^{2}$ at 20-8-2016. Statistical analysis showed significant differences at level 0.05 among A. m. carnica, A. m. Native and A. m. ligustica. Hossam et al. (2012) and Contreras et al. (2013) also found, that all daily activities and patterns of forager honeybees are under the control and/or change with weather conditions.

Table 10. Effect of some honeybee races and environmental factors on sealed brood area in summer 2016-2017

\begin{tabular}{|c|c|c|c|c|c|c|}
\hline Summer & \multicolumn{3}{|c|}{ Honeybee race } & \multirow{2}{*}{ Mean } & Temperature & $\begin{array}{c}\text { Relative } \\
\text { humidity \% }\end{array}$ \\
\hline Period & $\begin{array}{c}\text { Apis mellifera } \\
\text { carnica }\end{array}$ & $\begin{array}{c}\text { Apis mellifera } \\
\text { ligustica }\end{array}$ & $\begin{array}{c}\text { Apis mellifera } \\
\text { local }\end{array}$ & & & \\
\hline $23 / 7 / 2016$ & $90.250 \mathrm{~g}$ & $93.000 \mathrm{~g}$ & $84.500 \mathrm{~g}$ & 89.250 & 34.05 & 25.85 \\
\hline $6 / 8 / 2016$ & $76.250 \mathrm{~g}$ & $72.250 \mathrm{~g}$ & $84.500 \mathrm{~g}$ & 77.660 & 43.95 & 24.30 \\
\hline $20 / 8 / 2016$ & $61.750 \mathrm{~g}$ & $61.250 \mathrm{~g}$ & $65.750 \mathrm{~g}$ & 62.916 & 42.50 & 26.95 \\
\hline $3 / 9 / 2016$ & $77.000 \mathrm{~g}$ & $76.500 \mathrm{~g}$ & $83.500 \mathrm{~g}$ & 79.000 & 34.50 & 35.70 \\
\hline $23 / 7 / 2017$ & $939.500 \mathrm{a}$ & $795.500 \mathrm{~b}$ & $948.250 \mathrm{a}$ & 894.410 & 32.75 & 24.15 \\
\hline $6 / 8 / 2017$ & $710.000 \mathrm{~b}$ & $560.500 \mathrm{~cd}$ & $715.750 \mathrm{~b}$ & 662.080 & 36.70 & 24.50 \\
\hline $20 / 8 / 2017$ & $497.250 \mathrm{def}$ & $421.000 \mathrm{f}$ & $588.250 \mathrm{~cd}$ & 502.160 & 34.60 & 26.44 \\
\hline $3 / 9 / 2017$ & $525.500 \mathrm{cde}$ & $440.250 \mathrm{ef}$ & $613.250 \mathrm{c}$ & 526.330 & 29.90 & 30.65 \\
\hline Mean & 372.187 & 315.031 & 397.968 & & 36.11 & 27.31 \\
\hline
\end{tabular}

Different letters mean significant difference $(\mathrm{p}<0.05)$ based on Duncan test.

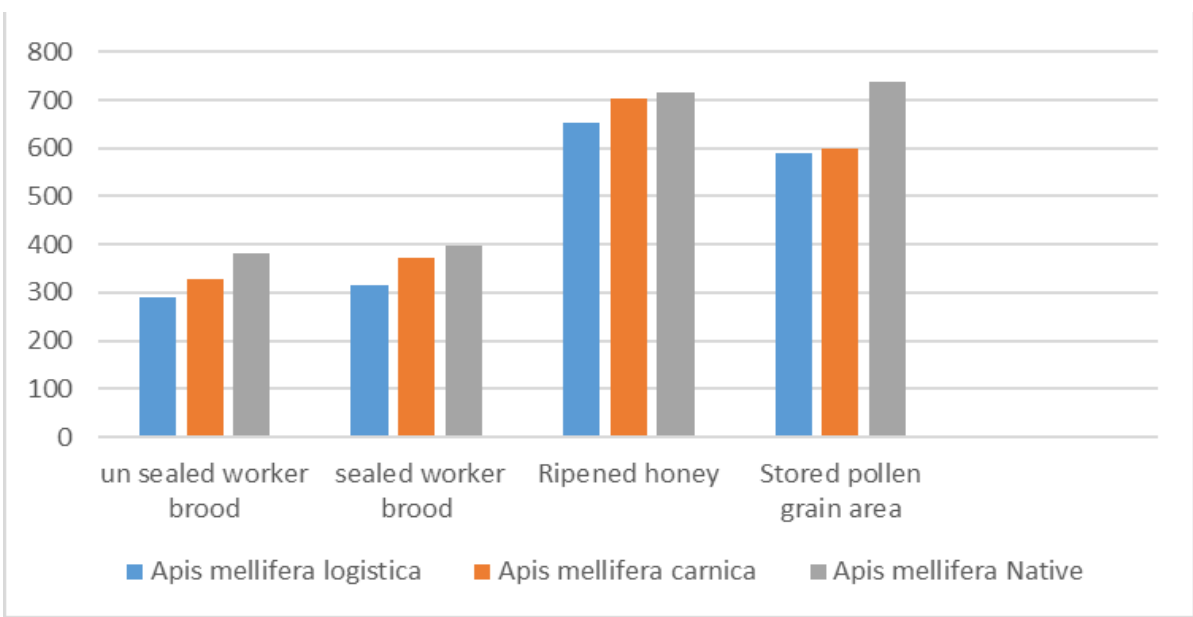

Figure 5. Effect of environmental factors on different the activities of honeybee races in summer

\section{Ripened honey area}

Table 11 shows the average ripened honey area in early summer. The highest average area for $A . m$. Native was $1431.000 \mathrm{inch}^{2}$ at 23-7-2017, when the average temperature was $32.75^{\circ} \mathrm{C}$ and relative humidity was $24.15 \%$. In comparison, the average area for $A . m$. 
carnica and A. m. ligustica were 1420.500 and 1370.750 inch $^{2}$ during the same period and weather conditions. The lowest average for A. m. ligustica was 257.000 inch $^{2}$ at 23-72016, when the average temperature and relative humidity were $34.05{ }^{\circ} \mathrm{C}$ and $25.85 \%$. The average of ripened honey area was $715.000,704.343$ and $651.468 \mathrm{inch}^{2}$ for $A$. $m$. Native A. m. carnica and A. m. ligustica respectively as shown in Figure 5. The highest general average was $1290.917 \mathrm{inch}^{2}$ at 6-8-2017 and the lowest was $54.833 \mathrm{inch}^{2}$ at 20-82016. Statistical analysis showed significant differences at level 0.05 among races. The results agree with Ali (2011), who found a high foraging rate of Yemeni honeybee in comparison to honey bees in Carniola during June and August and at different times of observation: 6-7 am, 11 to 12 am, and 4 to $5 \mathrm{pm}$.

Table 11. Effect of some honeybee races and environmental factors on sealed honey area in summer 2016-2017

\begin{tabular}{|c|c|c|c|c|c|c|}
\hline Summer & \multicolumn{3}{|c|}{ Honeybee race } & \multirow{2}{*}{ Mean } & Temperature & $\begin{array}{c}\text { Relative } \\
\text { humidity \% }\end{array}$ \\
\hline $23 / 7 / 2016$ & $264.500 \mathrm{~d}$ & $257.000 \mathrm{~d}$ & $269.500 \mathrm{~d}$ & 263.666 & 34.05 & 25.85 \\
\hline $6 / 8 / 2016$ & $275.500 \mathrm{~d}$ & $271.250 \mathrm{~d}$ & $275.500 \mathrm{~d}$ & 274.083 & 43.95 & 24.30 \\
\hline $20 / 8 / 2016$ & $55.000 \mathrm{e}$ & $46.000 \mathrm{e}$ & $63.500 \mathrm{e}$ & 54.833 & 42.50 & 26.95 \\
\hline $3 / 9 / 2016$ & $84.750 \mathrm{e}$ & $87.000 \mathrm{e}$ & $87.000 \mathrm{e}$ & 86.250 & 34.50 & 35.70 \\
\hline $23 / 7 / 2017$ & $1420.5000 \mathrm{a}$ & $1370.750 \mathrm{a}$ & $1431.000 \mathrm{a}$ & 1407.417 & 32.75 & 24.15 \\
\hline $6 / 8 / 2017$ & $1333.250 \mathrm{a}$ & $1186.250 \mathrm{~b}$ & $1353.250 \mathrm{a}$ & 1290.917 & 36.70 & 24.50 \\
\hline $20 / 8 / 2017$ & $1165.750 \mathrm{~b}$ & $1020.000 \mathrm{c}$ & $1198.750 \mathrm{~b}$ & 1128.167 & 34.60 & 26.44 \\
\hline $3 / 9 / 2017$ & $1035.500 \mathrm{c}$ & $973.500 \mathrm{c}$ & $1041.500 \mathrm{c}$ & 1016.833 & 29.90 & 30.65 \\
\hline Mean & 704.343 & 651.468 & 715.000 & & 36.11 & 27.31 \\
\hline
\end{tabular}

Different letters mean significant difference $(\mathrm{p}<0.05)$ based on Duncan test.

\section{Stored pollen grain area}

Table 12 and Figure 5 show the average stored pollen grain area in summer. The highest average area for $A$. $m$. Native was 1582.750 inch $^{2}$ at 23-7-2017, when the average temperature was $32.75^{\circ} \mathrm{C}$ and the relative humidity was $24.15 \%$. The average area for A. m carnica and A. m ligustica were 1205.250 and $1191.500 \mathrm{inch}^{2}$ during the same period and with the same weather conditions. In comparison, the lowest average was $7.290 \mathrm{inch}^{2}$ for the $A . m$ Native at 3-9-2016 when the average temperature and relative humidity was $34.50{ }^{\circ} \mathrm{C}$ and $35.70 \%$.

Table 12. Effect of some honeybee races and environmental factors on pollen grain area in summer 2016-2017

\begin{tabular}{|c|c|c|c|c|c|c|}
\hline Summer & \multicolumn{3}{|c|}{ Honey bee race } & \multirow{2}{*}{ Mean } & Temperature & $\begin{array}{c}\text { Relative } \\
\text { humidity \% }\end{array}$ \\
\cline { 1 - 4 } Period & $\begin{array}{c}\text { Apis mellifera } \\
\text { carnica }\end{array}$ & $\begin{array}{c}\text { Apis mellifera } \\
\text { ligustica }\end{array}$ & $\begin{array}{c}\text { Apis mellifera } \\
\text { Native }\end{array}$ & & & 25.05 \\
\hline $23 / 7 / 2016$ & $69.500 \mathrm{ij}$ & $86.250 \mathrm{i}$ & $60.250 \mathrm{ij}$ & 72.000 & 34.05 & 25.85 \\
\hline $6 / 8 / 2016$ & $76.000 \mathrm{ij}$ & $62.000 \mathrm{ij}$ & $51.750 \mathrm{ij}$ & 63.250 & 43.95 & 24.30 \\
\hline $20 / 8 / 2016$ & $55.000 \mathrm{ij}$ & $46.000 \mathrm{ij}$ & $63.500 \mathrm{ij}$ & 54.833 & 42.50 & 26.95 \\
\hline $3 / 9 / 2016$ & $22.500 \mathrm{ij}$ & $38.750 \mathrm{ij}$ & $7.290 \mathrm{j}$ & 22.846 & 34.50 & 35.70 \\
\hline $23 / 7 / 2017$ & $1205.250 \mathrm{de}$ & $1191.500 \mathrm{de}$ & $1582.750 \mathrm{a}$ & 1326.500 & 32.75 & 24.15 \\
\hline
\end{tabular}




\begin{tabular}{|c|c|c|c|c|c|c|}
\hline $6 / 8 / 2017$ & $1178.250 \mathrm{ef}$ & $1163.500 \mathrm{ef}$ & $1511.500 \mathrm{~b}$ & 1284.417 & 36.70 & 24.50 \\
\hline $20 / 8 / 2017$ & $1116.250 \mathrm{fg}$ & $1094.000 \mathrm{~g}$ & $1374.750 \mathrm{c}$ & 1195.000 & 34.60 & 26.44 \\
\hline $3 / 9 / 2017$ & $1065.500 \mathrm{gh}$ & $1027.000 \mathrm{~h}$ & $1248.250 \mathrm{~d}$ & 1113.583 & 29.90 & 30.65 \\
\hline Mean & 598.531 & 588.625 & 737.505 & & 36.11 & 27.31 \\
\hline
\end{tabular}

Different letters mean significant difference $(\mathrm{p}<0.05)$ based on Duncan test.

The average of stored pollen area was 598.531, 588.625 and 737.505 inch $^{2}$ for $A . m$ carnica, A. $m$ ligustica and A. $m$. Native respectively, when the temperature was $36.11^{\circ} \mathrm{C}$ and the average relative humidity was $27.31 \%$. The highest general average was $1326.500 \mathrm{inch}^{2}$ at 23-7-2017 and the lowest was 22.846 inch $^{2}$ at 3-9-2016. Statistical analysis showed significant differences at level 0.05 between all races. These results show a low amount of pollen, while Pernal and Currie (2010) found, that in the absence of pollen or with poor pollen quality, colonies of honeybees increase the proportion of pollen foragers without increasing the rate of foraging.

\section{Effect of environmental factors on bioactivity of honey bee colonies in autumn}

\section{Unsealed workers brood area}

Table 13 shows the average unsealed workers brood area in autumn. The highest average unsealed brood area for $A$. $m$. carnica at 29-10-2017 was 487.000 inch $^{2}$, when the average temperature was $19.50^{\circ} \mathrm{C}$ and the average relative humidity was $52.75 \%$. The average unsealed brood area for $A$. $m$. ligustica and $A$. $m$. Native was 477.750 and $456.750 \mathrm{inch}^{2}$ during the same period and weather conditions, while the lowest average of unsealed brood area was $18.500 \mathrm{inch}^{2}$ for $A$. $m$. Native at 29-10-2016 when the average temperature and relative humidity were $22.55^{\circ} \mathrm{C}$ and $44.4 \%$ respectably.

Table 13. Effect of some honeybee races and environmental factors on unsealed brood area in autumn 2016-2017

\begin{tabular}{|c|c|c|c|c|c|c|}
\hline Autumn & \multicolumn{3}{|c|}{ Honey bee race } & \multirow{2}{*}{ Mean } & Temperature & $\begin{array}{c}\text { Relative } \\
\text { humidity \% }\end{array}$ \\
\cline { 1 - 4 } Period & $\begin{array}{c}\text { Apis mellifera } \\
\text { carnica }\end{array}$ & $\begin{array}{c}\text { Apis mellifera } \\
\text { ligustica }\end{array}$ & $\begin{array}{c}\text { Apis mellifera } \\
\text { Native }\end{array}$ & & & \\
\hline $17 / 9 / 2016$ & $90.250 \mathrm{hijk}$ & $133.250 \mathrm{gh}$ & $77.000 \mathrm{ijkl}$ & 100.166 & 29.75 & 38.50 \\
\hline $1 / 10 / 2016$ & $103.500 \mathrm{ghij}$ & $148.250 \mathrm{~g}$ & $77.000 \mathrm{ijkl}$ & 109.583 & 27.50 & 40.05 \\
\hline $15 / 10 / 2016$ & $59.000 \mathrm{ijklm}$ & $109.500 \mathrm{ghi}$ & $40.000 \mathrm{klm}$ & 69.500 & 24.75 & 42.00 \\
\hline $29 / 10 / 2016$ & $30.250 \mathrm{~lm}$ & $54.500 \mathrm{jklm}$ & $18.500 \mathrm{~m}$ & 34.416 & 22.55 & 44.40 \\
\hline $17 / 9 / 2017$ & $364.250 \mathrm{bc}$ & $320.250 \mathrm{~cd}$ & $473.500 \mathrm{a}$ & 386.000 & 27.45 & 33.50 \\
\hline $1 / 10 / 2017$ & $307.500 \mathrm{de}$ & $270.750 \mathrm{ef}$ & $373.750 \mathrm{~b}$ & 317.333 & 22.50 & 36.75 \\
\hline $15 / 10 / 2017$ & $253.000 \mathrm{f}$ & $257.250 \mathrm{f}$ & $260.500 \mathrm{ef}$ & 256.916 & 20.65 & 40.05 \\
\hline $29 / 10 / 2017$ & $487.000 \mathrm{a}$ & $477.750 \mathrm{a}$ & $456.750 \mathrm{a}$ & 473.833 & 19.50 & 52.75 \\
\hline Mean & 211.843 & 221.437 & 222.125 & & 24.33 & 41.00 \\
\hline
\end{tabular}

Different letters mean significant difference $(\mathrm{p}<0.05)$ based on Duncan test.

The average of unsealed workers brood area was $222.125,221.4375$ and $211.8438 \mathrm{inch}^{2}$ for A. m. Native, A. m. ligustica and A. m. carnica respectively, when the average temperature was $24.33^{\circ} \mathrm{C}$ and the average relative humidity was $41.00 \%$ as shown in 
Figure 6. The highest general average was 473.833 inch $^{2}$ at 29-10-2017 and the lowest was 34.41667 inch $^{2}$ at 29-10-2016. Statistical analysis showed significant differences at level 0.05 among $A$. m. carnica, $A$. $m$. local and $A$. $m$. ligustica. The results agree with Taragany (2008), who found that the highest means of the unsealed brood area and sealed brood area can be detected in autumn, when they are fed extra sugar solution and vice versa.

\section{Sealed workers brood area}

Table 14 and Figure 6 show the average sealed brood area of the workers in autumn. The highest average sealed brood area for $A$. $m$. Native $563.000 \mathrm{inch}^{2}$ at 17-9-2017, when the average temperature was $27.45^{\circ} \mathrm{C}$ and the average relative humidity was $33.50 \%$. In comparison, the average sealed brood area for A. m. carnica and A. $\mathrm{m}$. ligustica was 480.500 and 396.500 inch $^{2}$ during the same period and weather conditions, while the lowest average of sealed brood was $22.000 \mathrm{inch}^{2}$ for $A . m$. Native at 29-10-2017, when the average temperature and relative humidity were $19.50{ }^{\circ} \mathrm{C}$ and $52.75 \%$. The average of sealed workers brood area was $160.468,151.437$ and 141.625 inch $^{2}$ for $A$. $m$. Native. A. m. ligustica and A. m. carnica respectively, when the average temperature was $24.33^{\circ} \mathrm{C}$ and the average relative humidity was $41.00 \%$. The highest general average was $480.000 \mathrm{inch}^{2}$ at 17-9-2017 and the lowest was $31.78333 \mathrm{inch}^{2}$ at 15-10-2016. Statistical analysis showed significant differences at level 0.05 among races. These result agree with Harbo (2015), who showed that the average number of adult bees declined steadily from 20800 in November to 12,000 in March. The brood in the colonies was small before the winter solstice, but soon increased.

Table 14. Effect of some honeybee races and environmental factors on sealed brood area in autumn 2016-2017

\begin{tabular}{|c|c|c|c|c|c|c|}
\hline Autumn & \multicolumn{3}{|c|}{ Honey bee race } & \multirow{2}{*}{ Mean } & \multirow{2}{*}{ Temperature } & $\begin{array}{c}\text { Relative } \\
\text { humidity \% }\end{array}$ \\
\cline { 1 - 4 } Period & $\begin{array}{c}\text { Apis mellifera } \\
\text { carnica }\end{array}$ & $\begin{array}{c}\text { Apis mellifera } \\
\text { ligustica }\end{array}$ & $\begin{array}{c}\text { Apis mellifera } \\
\text { Native }\end{array}$ & & & \\
\hline $17 / 9 / 2016$ & $84.750 \mathrm{fg}$ & $142.500 \mathrm{e}$ & $82.250 \mathrm{fg}$ & 103.166 & 29.75 & 38.50 \\
\hline $1 / 10 / 2016$ & $52.750 \mathrm{fg}$ & $110.000 \mathrm{ef}$ & $52.000 \mathrm{fg}$ & 71.583 & 27.50 & 40.05 \\
\hline $15 / 10 / 2016$ & $22.350 \mathrm{~g}$ & $48.000 \mathrm{fg}$ & $25.000 \mathrm{~g}$ & 31.783 & 24.75 & 42.00 \\
\hline $29 / 10 / 2016$ & $22.750 \mathrm{~g}$ & $51.000 \mathrm{fg}$ & $23.000 \mathrm{~g}$ & 32.250 & 22.55 & 44.40 \\
\hline $17 / 9 / 2017$ & $480.500 \mathrm{~b}$ & $396.500 \mathrm{~cd}$ & $563.000 \mathrm{a}$ & 480.000 & 27.45 & 33.50 \\
\hline $1 / 10 / 2017$ & $424.500 \mathrm{c}$ & $359.500 \mathrm{~d}$ & $492.000 \mathrm{~b}$ & 425.333 & 22.50 & 36.75 \\
\hline $15 / 10 / 2017$ & $22.650 \mathrm{~g}$ & $54.000 \mathrm{fg}$ & $24.500 \mathrm{~g}$ & 32.383 & 20.65 & 40.05 \\
\hline $29 / 10 / 2017$ & $22.750 \mathrm{~g}$ & $50.000 \mathrm{fg}$ & $22.000 \mathrm{~g}$ & 32.916 & 19.50 & 52.75 \\
\hline Mean & 141.625 & 151.437 & 160.468 & & 24.33 & 41.00 \\
\hline
\end{tabular}

Different letters mean significant difference $(\mathrm{p}<0.05)$ based on Duncan test.

\section{Ripened honey area}

Table 15 shows the average ripened honey area in early summer. The highest average area for $A$. $m$. Native was $991.500 \mathrm{inch}^{2}$ at 17-9-2017 when the average temperature was $27.45^{\circ} \mathrm{C}$ and the relative humidity was $33.50 \%$. The average area for A. m carnica and A. m ligustica was 957.750 and $917.000 \mathrm{inch}^{2}$ during the same period and weather conditions. In 
comparison, the lowest average for $A$. $m$. Native was $106.750 \mathrm{inch}^{2}$ at 17-9-2016, when the average temperature and relative humidity were $29.75^{\circ} \mathrm{C}$ and $38.50 \%$. The average of ripened honey area was 400.437, 387.281 and 383.406 inch $^{2}$ for $A$. $m$ Native, $A$. $m$ ligustica and A. $m$ carnica respectively as shown in Figure 6. The highest general average was 955.416 inch $^{2}$ at 17-9-2017 and the lowest was 127.000 inch $^{2}$ at 17-9-2016. Statistical analysis showed significant differences at level 0.05 among A. m. carnica, A. $m$. Native and $A$. $m$. ligustica. Results agree with Bas (2013) who recorded that the highest rate of stored pollen area in autumn was 9.83 inch $^{2}$ when fed with multi- vitamin and vice versa.

Table 15. Effect of some honeybee races and environmental factors on ripened honey area in autumn 2016-2017

\begin{tabular}{|c|c|c|c|c|c|c|}
\hline Autumn & \multicolumn{3}{|c|}{ Honey bee race } & \multirow{2}{*}{ Mean } & Temperature & $\begin{array}{c}\text { Relative } \\
\text { humidity \% }\end{array}$ \\
\cline { 1 - 4 } & $\begin{array}{c}\text { Apis mellifera } \\
\text { carnica }\end{array}$ & $\begin{array}{c}\text { Apis mellifera } \\
\text { ligustica }\end{array}$ & $\begin{array}{c}\text { Apis mellifera } \\
\text { Native }\end{array}$ & & & \\
\hline $17 / 9 / 2016$ & $136.500 \mathrm{hi}$ & $137.750 \mathrm{hi}$ & $106.750 \mathrm{i}$ & 127.000 & 29.75 & 38.50 \\
\hline $1 / 10 / 2016$ & $180.000 \mathrm{fghi}$ & $177.500 \mathrm{fghi}$ & $156.250 \mathrm{ghi}$ & 171.250 & 27.50 & 40.05 \\
\hline $15 / 10 / 2016$ & $200.250 \mathrm{efgh}$ & $219.250 \mathrm{defg}$ & $205.750 \mathrm{efgh}$ & 208.416 & 24.75 & 42.00 \\
\hline $29 / 10 / 2016$ & $240.000 \mathrm{def}$ & $276.750 \mathrm{de}$ & $295.000 \mathrm{~d}$ & 270.583 & 22.55 & 44.40 \\
\hline $17 / 9 / 2017$ & $957.750 \mathrm{ab}$ & $917.000 \mathrm{abc}$ & $991.500 \mathrm{a}$ & 955.416 & 27.45 & 33.50 \\
\hline $1 / 10 / 2017$ & $912.500 \mathrm{bc}$ & $874.000 \mathrm{c}$ & $947.500 \mathrm{abc}$ & 911.333 & 22.50 & 36.75 \\
\hline $15 / 10 / 2017$ & $200.250 \mathrm{efgh}$ & $219.250 \mathrm{defg}$ & $205.750 \mathrm{efgh}$ & 208.416 & 20.65 & 40.05 \\
\hline $29 / 10 / 2017$ & $240.000 \mathrm{def}$ & $276.750 \mathrm{de}$ & $295.000 \mathrm{~d}$ & 270.583 & 19.50 & 52.75 \\
\hline Mean & 383.406 & 387.281 & 400.437 & & 24.33 & 41.00 \\
\hline
\end{tabular}

Different letters mean significant difference $(\mathrm{p}<0.05)$ based on Duncan test.

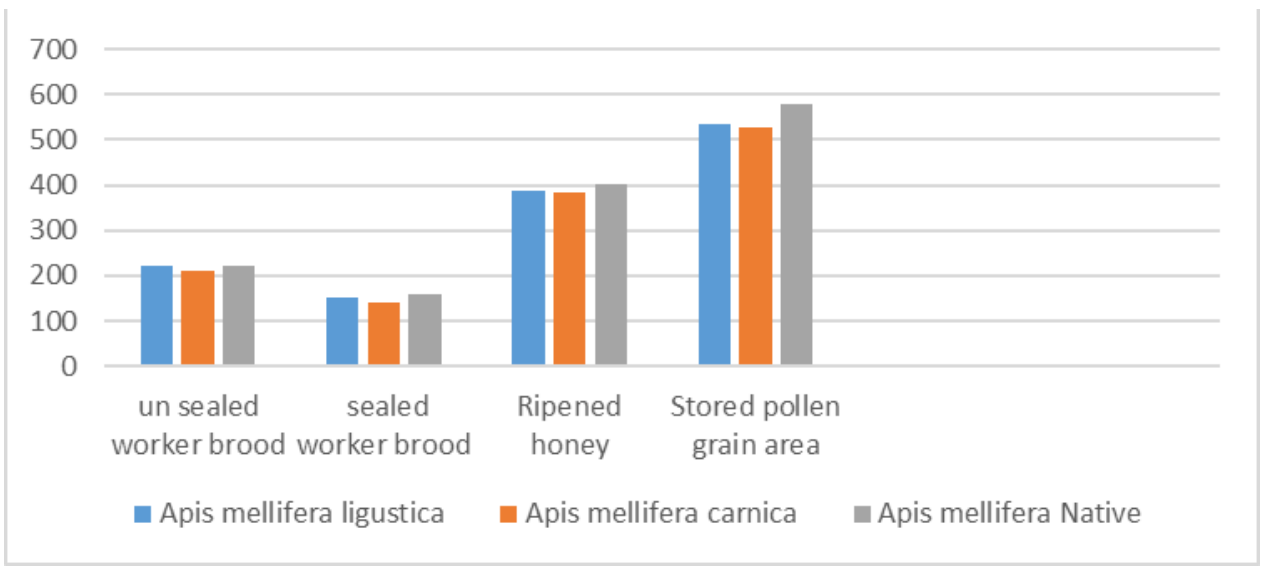

Figure 6. Effect of environmental factors on different the activities of honeybee races in autumn

\section{Stored pollen grain area}

Table 16 and Figure 6 show the average stored pollen grain area in autumn. The highest average area for $A$. $m$. Native was 1196.250 inch $^{2}$ at 17-9-2017, when the average temperature was $27.45^{\circ} \mathrm{C}$ and relative humidity was $33.50 \%$. The average area for A. m. carnica and A. m. ligustica was 1017.250 and $982.500 \mathrm{inch}^{2}$ during the same period and with the same weather conditions. In comparison, the lowest average was 
32.000 inch $^{2}$ for $A . m$. Native at 15-10-2016, when the average temperature and relative humidity were $24.75^{\circ} \mathrm{C}$ and $42 \%$. The average of stored pollen area was 580.937, 533.812 and $527.250 \mathrm{inch}^{2}$ for A. m. Native, A. m. ligustica and A. m. carnica respectively, when the temperature was $24.33^{\circ} \mathrm{C}$ and the average relative humidity was $41.00 \%$. The highest general average was 1065.333 inch $^{2}$ at 17-9-2017 and the lowest was 63.833 inch $^{2}$ at 15-10-2016. Statistical analysis showed significant differences at level 0.05 between all races. The results are in agreement with Tan et al. (2012), who found that $A$. cerana began foraging earlier and at lower temperatures than A. mellifera did. A. cerana foraging (departures per minute) reached its peak early and at a lower temperature than $A$. mellifera foraging did.

Table 16. Effect of some honeybee races and environmental factors on pollen grain area in autumn 2016-2017

\begin{tabular}{|c|c|c|c|c|c|c|}
\hline Autumn & \multicolumn{3}{|c|}{ Honeybee race } & \multirow{2}{*}{ Mean } & Temperature & $\begin{array}{c}\text { Relative } \\
\text { humidity \% }\end{array}$ \\
\hline Period & $\begin{array}{c}\text { Apis mellifera } \\
\text { carnica }\end{array}$ & $\begin{array}{c}\text { Apis mellifera } \\
\text { ligustica }\end{array}$ & $\begin{array}{c}\text { Apis mellifera } \\
\text { Native }\end{array}$ & & & \\
\hline $17 / 9 / 2016$ & $109.250 \mathrm{fgh}$ & $130.500 \mathrm{f}$ & $64.500 \mathrm{ghij}$ & 101.416 & 29.75 & 38.50 \\
\hline $1 / 10 / 2016$ & $93.500 \mathrm{fghi}$ & $115.750 \mathrm{fg}$ & $50.250 \mathrm{ij}$ & 86.500 & 27.50 & 40.05 \\
\hline $15 / 10 / 2016$ & $65.250 \mathrm{ghij}$ & $94.250 \mathrm{fghi}$ & $32.000 \mathrm{j}$ & 63.833 & 24.75 & 42.00 \\
\hline $29 / 10 / 2016$ & $87.000 \mathrm{fghi}$ & $98.000 \mathrm{fghi}$ & $55.750 \mathrm{hij}$ & 80.250 & 22.55 & 44.40 \\
\hline $17 / 9 / 2017$ & $1017.250 \mathrm{c}$ & $982.500 \mathrm{~cd}$ & $1196.250 \mathrm{a}$ & 1065.333 & 27.45 & 33.50 \\
\hline $1 / 10 / 2017$ & $976.500 \mathrm{~cd}$ & $952.750 \mathrm{~d}$ & $1133.750 \mathrm{~b}$ & 1021.000 & 22.50 & 36.75 \\
\hline $15 / 10 / 2017$ & $978.750 \mathrm{~cd}$ & $957.750 \mathrm{~d}$ & $1116.250 \mathrm{~b}$ & 1017.583 & 20.65 & 40.05 \\
\hline $29 / 10 / 2017$ & $943.000 \mathrm{~d}$ & $886.500 \mathrm{e}$ & $998.750 \mathrm{~cd}$ & 942.750 & 19.50 & 52.75 \\
\hline Mean & 533.812 & 527.250 & 580.937 & & 24.33 & 41.00 \\
\hline
\end{tabular}

Different letters mean significant difference $(\mathrm{p}<0.05)$ based on Duncan test.

\section{Stages of fat bodies during the life of honey bees}

This study also aimed to explain the stages of fat bodies throughout the life of honey bees as shown in Plate 1:

a. Perivisceral fat bodies in one day old workers appeared with a dense inclusion, dark color and a thick wall with invisible nucleus.

b. Perivisceral fat bodies in seven day old workers of Apis mellifera carnica: A new generation of fat bodies, slightly larger with vacuolization features inside, and course, thick walls as result of newly emerging in spring.

c. Perivisceral fat bodies in fourteen day old worker of Apis mellifera carnica in spring: The fat cell was very large, it vacuolated various shapes, and had thick walls, light blue in color.

d. Perivisceral fat bodies in twenty one day old worker of Apis mellifera Native in spring: The fat bodies were similar to twenty one day old workers of Apis mellifera ligustica in spring, but were larger in size.

e. Perivisceral fat bodies in twenty eight day old worker of Apis mellifera Native in spring: These showed very obvious and clear features, loaded with a dense inclusion, some nucleus and variously shaped, dark purple, vacuolated cells. 


$$
\text { - } 1376 \text { - }
$$
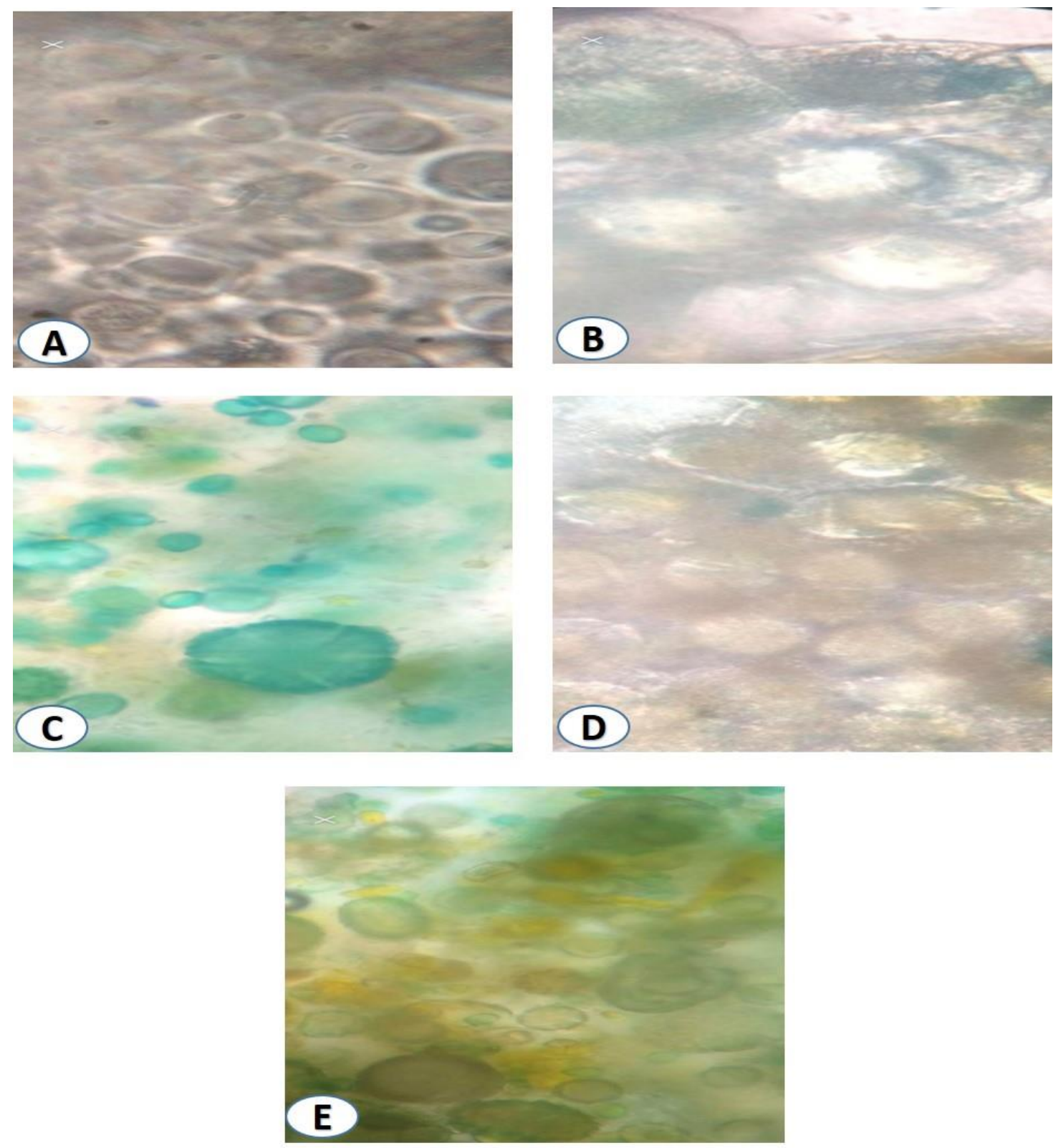

Plate 1. Stages of fat bodies during the life of honey bees (40X)

\section{Conclusion}

The results of the field experiment revealed the direct effect of environmental conditions (Temperature and relative humidity) on three races of honeybees. It was conducted for two years in different seasons. Comparing the two races (Apis mellifera carnica and Apis mellifera ligustica) native to the country with Apis mellifera Native during the first year, Apis mellifera Native are more affected by environmental factors than the other two races (Apis mellifera carnica and Apis mellifera ligustica). The results showed the highest rate of unsealed brood area of Apis mellifera Native race to be in the early summer of 2016 and the lowest rate of Apis mellifera ligustica in spring 2017. The sealed brood area of the Apis mellifera Native strain was the highest in early summer, and the lowest rate of Apis mellifera Native strain was in autumn 2017. The 
highest and the lowest rate of pollen grain area for Apis mellifera Native strain were detected in the summer season of 2017 and 2016 respectively. We also studied the fat body difference through the stages of life for honeybees.

The highest and the lowest rate of Pollen grain area were (1582.750 and 7.290) inch for Apis mellifera Native strain in summer 2017 and 2016 respectively.

\section{REFERENCES}

[1] Abou-Shaara, H. F. (2012): Notes on water collection by honey bees. - Bee World 89: 50-51.

[2] Abou-Shaara, H. F. (2014): The foraging behavior of honey bees, Apis mellifera. Faculty of Agriculture, Damanhour University, Egypt. - Veterinarni Medicina 59(1): 1-10.

[3] Ali, M. A. M. (2011): Comparative study for evaluating two honey bee races, Apis mellifera jementica (indigenous race) and Apis mellifera carnica (carniolan race) in brood production, population development and foraging activity under the environmental conditions of the central region of the Kingdom of Saudi Arabia. - Annals of Agricultural Sciences 56: 127-134.

[4] Alqarni, A. S. (2006): Tolerance of summer temperature in imported and indigenous honeybee Apis mellifera L. Races in central Saudi Arabia. - Saudi Journal of Biological Sciences 13: 123-127.

[5] Ayoub, Z. N. (2011): Workers ontogeny in queen less or brood less colonies of honey bee (Apis mellifera L.). - Ph. D. Thesis. Faculty of Biology and Earth Science, Jagiellonian University, Poland.

[6] Bas, S. M. A. (2013): A study of the effect of some pollen supplemental food on body organs of honeybee workers and their activities Apis mellifera L. (HYMENOPTERA: APIDAE). - M. Sc. Thesis. College of Agriculture, Univ of Dohuk.

[7] Becher, M. A., Scharpenberg, H., Moritz, R. F. A. (2009): Pupal developmental temperature and behavioral specialization of honeybee workers (Apis mellifera L.). - J. Comp. Physiol. A. DOI: 10.1007/s00359-009-0442-7.

[8] Blazyte-Cereskiene, L., Vaitkeviciene, G., Venskutonyteand, S., Buda, V. (2010): Honey bee foraging in spring oilseed rape crops under high ambient temperature conditions. Zemdirbyste-Agriculture 97: 61-70.

[9] Chapman, R. F. (1978): The Insect Structure and Function. - Engl. Univ. Press. Ltd., London, England.

[10] Contreras, H. L., Goyret, J., Arx, M. v., Pierce, C. T., Bronstein, J. L., Raguso, R. A., Davidowitz, G. (2013): The effect of ambient humidity on the foraging behavior of the hawkmoth Manduca sexta. - Journal of Comparative Physiology 199(11): 1053-63.

[11] Fathy, H. M. (1997): Honey bee colony population in relation to brood rearing and stored pollen. - Archives of Phytopathology and Plant Protection 30(5): 445-452.

[12] Harbo, J. R. (2015): Effect of brood rearing on honey consumption and the survival of worker honey bees. - Journal of Apicultural Research 32(1): 11-17.

[13] Hossam, F. A., Ahmad, A. A., Abdelsalam, A. M. (2012): Tolerance of two honey bee races to various temperature and relative humidity gradients. - Environmental and Experimental Biology 10: 133-138.

[14] Joshi, N. C., Joshi, P. C. (2010): Foraging behaviour of Apis spp. on apple flowers in a subtropical environment. - NY Sci. J. 3: 71-76.

[15] Mahmoud, T. T. (1992): Comparative anatomical and histological study of the heart of four syrphid species (Diptera:syrphidae) in Iraq. - Pak. J. Sci. Ind. Res. 35(5): 182-184.

[16] Mattu, V. K, Raj, H., Thakur, M. L. (2012): Foraging behavior of honeybees on apple crop and its variation with altitude in Shimla hills of western Himalaya. - International Journal of Science and Nature 3: 296-301. 
[17] Mesbah, H. A. A., El-Sayed, N. A. A., Hassona, N. K., Abdel-Hameed, K. M. A., AbdelSattar, H. A. S. (2017): The Common types of pollen grains collected by honey bee workers Apis mellifera, L. (Hymenoptera. Apidae) in El-Sabheia Region, Alexandria Governorate, Egypt. - Alexandria Science Exchange Journal: An International Quarterly Journal of Science Agricultural Environments 38(October-December): 913-920.

[18] Mustafa, A. O. (2003): Effect some of geographic local within Erbil vision in bioactivity of honey bee colonies. - M. Sc. Thesis. College of Agriculture, Salahadin University, Erbil.

[19] Neupane, K. R., Thapa, R. B. (2005): Alternative to off-season sugar supplement feeding of honey bees. - J. Inst. Agric. Anim. Sci. 26: 77-81.

[20] Olivera,V. T. P., Cruz-Landim, C.(2003): Morphology and function of insect fat body cells: A review. - Biociencias Proto Algre 11(2): 195-205.

[21] Pernal, S. F., Currie, R. W. (2010): The influence of pollen quality on foraging behavior in honeybees (Apis mellifera L.). - Behavioral Ecology and Sociobiology 51: 53-68.

[22] Petz, M., Stabentheiner, A., Crailsheim, K. (2004). Respiration of individual honeybee larvae in relation to age and ambient temperature. - J. Compar. Physiol. B 174: 511-518.

[23] Reddy, P. V. R., Rashmi, T., Varum Rajan, V., Verghese, A. (2012): Foraging activity of honeybee in relation to weather parameters. - Paper presented in 4th National Symposium on Plant Protection in Horticultural Crops, Bangalore, 24-27 April, 2012.

[24] Roma, G. C., Bueno, O. C., Camargo-Mathias, M. I. (2010): Morpho-physiological analysis of the insect fat body: a review. - Micron 41: 395-401.

[25] Shamdin, Z. N. (2003): Effect of supplemental protein and vitamins on the development of specific tissues with special concern to their fine structure in relation to the activity of honey bee workers Apis mellifera L. (Hymenoptera:Apidae). - M.Sc. Thesis. College of Agriculture, Univ of Dohuk.

[26] Snodgrass, R. E., Erickson, E. H. (2003): The Hive and Honey Bee: The Anatomy of Honey Bee. - Revised edition by J. M. Graham. Dadant \& Sons, Hamilton, Illionis, USA.

[27] Tan, K., Yang, S., Wang, Z.-W., Radloff, S. E., Oldroyd, B. P. (2012): Differences in foraging and broodnest temperature in the honey bees Apis cerana and A. mellifera. Apidologie 43(6): 618-623.

[28] Targany, Y. M. A. (2008): Effect of rich proteins diet on the activities of honey bee colonies Apis mellifera L. (Hymenopter: Apidae). - M.Sc. Thesis. College of Agriculture, Univ of Salahaddin, Erbil.

[29] Tirado, R.,Simon, G., Johnston, P. (2013): Bees in Decline: A Review of Factors That Put Pollinators and Agriculture in Europe at Risk. - Greenpeace Research Laboratories Technical Report (Review). Greenpeace International, Amsterdam, The Netherlands.

[30] XLSTAT (2017): Data Analysis and Statistical Solution for Microsoft Excel. Addinsoft, Paris, France 2, JMP, Version 12. - SAS Institute Inc., Cary, NC.

[31] Zanini, D. A., Caetano, F. H. (2003): Ultra structure of the visceral fat body of the Wasp Michocyttarus Cerberus styx. (Hymenoptera:Vespidae). - Acta Microscopica12(B): 593.

\section{ELECTRONIC APPENDICES}

Appendix 1: Pollen 2016

Appendix 2: Pollen 2017

Appendix 3: Pollen 2016-2017

Appendix 4: Ripened honey 2016

Appendix 5: Ripened honey 2017 
Appendix 6: Ripened honey 2016-2017

Appendix 7: Sealed brood 2016

Appendix 8: Sealed brood 2017

Appendix 9: Sealed brood 2016-2017

Appendix 10: Unsealed brood 2016

Appendix 11: Unsealed brood 2017

Appendix 12: Unsealed brood 2016-2017 